\title{
Quality of Life of Chronic Heart Failure Patients
}

\author{
Lipy Lucy Costa1, Md. Shariful Islam1, Mohammad Nurul Anowar1, Md. Abdul Latif ${ }^{2}$ \\ ${ }^{1}$ Faculty of Adult \& Elderly Health Nursing, NIANER, Dhaka, Bangladesh \\ ${ }^{2}$ Faculty of Nursing Management, NIANER, Dhaka, Bangladesh \\ Email:lipylucycosta@gmail.com
}

How to cite this paper: Costa, L.L., Islam, Md.S., Anowar, M.N. and Latif, Md.A. (2020) Quality of Life of Chronic Heart Failure Patients. Open Journal of Nursing, 10, 831857.

https://doi.org/10.4236/ojn.2020.109058

Received: July 15, 2020

Accepted: September 14, 2020

Published: September 17, 2020

Copyright $\odot 2020$ by author(s) and Scientific Research Publishing Inc. This work is licensed under the Creative Commons Attribution International License (CC BY 4.0).

http://creativecommons.org/licenses/by/4.0/ (c) (i) Open Access

\begin{abstract}
Background: Chronic Heart Failure is a complex clinical conditions affecting patients' Quality of Life (QoL) globally. Objective: The aim of the study was to identify the factors influencing the quality of life of the chronic heart failure patients. Methods: A descriptive exploratory study was carried out by face-to-face interview with structured standard questionnaire. One hundred and forty two hospitalized chronic heart failure patients were conveniently recruited from National Institute of Cardiovascular Disease and Hospital, Shere-Bangla Nagar, Dhaka, Bangladesh. Data were collected from January to February, 2019. Quality of life related factors were identified using Patients' General Characteristics Questionnaire. QOL of chronic heart failure patients was measured by the Minnesota Living with Heart Failure Questionnaire (MLHFQ) and the World Health Organization's Quality of Life InstrumentShort Version (WHOQOL-BREF). Descriptive statistic was used to describe the samples' characteristics. Association between Socio-demographic characteristics and QOL of chronic heart failure patients was measured using t-test and one way of ANOVA. Relationship between continuous variables was measured by Pearson correlation test. Results: Findings reveal that mean of the total chronic heart failure related quality of life was $94.16(\mathrm{SD}=3.20)$ out of maximum of 105 . This high score indicates worsen chronic heart failure patients' quality of life. The mean score of general quality of life of chronic heart failure patients was calculated as 41.05 ( $\mathrm{SD}=5.109)$ out of maximum of 130 which indicates low level of general quality of life of chronic heart failure patients. There is a significant positive correlation found between disease related quality of life and general quality of life of chronic heart failure patients. Dimensions of physical $(r=0.248, p=0.000)$, mental $(r=-0.180, p<0.001)$ and total $(\mathrm{r}=-0.141, \mathrm{p}<0.001)$ of MLHFQ were significantly correlated with psychological dimension of WHOQOL-BREF except total two dimensions of its. Gender, marital status, education, income, smoking, residence and BMI were identified as factors having an effect on QOL of Chronic Heart Failure patients. Conclusion: Further intervention study is necessary to improve the
\end{abstract}


quality of life of chronic heart failure patients.

\section{Keywords}

Chronic Heart Failure, Quality of Life, Predictive Factors

\section{Introduction}

Chronic Heart Failure (CHF) is a complex clinical conditions influencing patients' Quality of Life (QOL) globally and its morbidity and mortality rate is increasing gradually [1] [2]. In Bangladesh, heart failure has been considered to be as the $4^{\text {th }}$ leading cause of disability and mortality [3]. Approximately 55,912 of patients suffer from heart failure every year in Bangladesh [4], whereas around 26 million people suffer from heart failure across the globe [5]. In contrast, in India post admission mortality was estimated from $20 \%$ to $30 \%$ [6]. Co-morbidity of chronic heart failure patients included as IHD, hypertension, diabetes mellitus and dilated cardiomyopathy [7]. Previous study found that CHF patients experience a lower QOL than general population due to advanced clinical symptoms, disability and hospitalization [8]. These patients usually have poor daily living activity as a result of dyspnea, shortness of breath, fatigue, pain, anorexia, sleep disturbance and constipation [9]. CHF causes increase in infection, maximum use of health care resources, increase in treatment cost, increase in lengthy of hospital stay and excessive burden to the family and society which ultimately decrease the QOL of CHF patients [1] [10].

QOL considered as a more holistic view of medicine, a decisive factor to understand the impact of diseases and improve the quality of medical care [11]. CHF not only increases the risk of morbidity, mortality, and worsens the patients' QOL, but also puts a huge burden on the overall health care system [12] [13]. One study reported poor QOL of CHF patients in all domains of physical component summary [14].

Various factors influence towards the QOL of patients with CHF. Those include modifiable and non-modifiable factors. Among modifiable factors, diabetes mellitus, systolic blood pressure, cardiomyopathy, antihypertensive medication use, hyperlipidemia, lipid-lowering medication use, use of hormone replacement therapy and lifestyle habits such as smoking status, physical inactivity and alcohol consumption were identified as critical factors for developing heart failure [15]. Prior study showed that hypertension was considered to be as the primary risk factor for developing heart failure in Bangladesh [16]. However personality, gender, age and heredity were identified as non-modifiable factors which constitute a good QOL [17]. Unmanageable factors contributed to developing complications such as pneumonia, pulmonary embolism, stroke, organ failure, sudden death and disabilities. These complications largely affected towards QOL of patients with CHF [18]. 
From the above discussion it is found that the factors influencing the QOL of CHF patients include personality, gender, age, diabetes mellitus, systolic blood pressure, cardiomyopathy, antihypertensive medication use, hyperlipidemia, lipid-lowering medication use, use of hormone replacement therapy and lifestyle habits. For promoting the quality of life it is necessary to identify the factors influencing quality of life of chronic heart failure patients. The study findings could act as a baseline data for further experimental study to evaluate the efficacy of lifestyle modification program for compromising these factors. It also provides necessary information for nurses to develop strategy for preventing factors influencing QOL of Chronic Heart Failure patient.

However, dearth of studies was conducted to identify the factors affecting the quality of life of CHF patients. Therefore, it is necessary to conduct this study at a specialized hospital in Bangladesh.

\section{Methods}

\subsection{Study Design}

A descriptive exploratory study design was conducted to identify the factors influencing the QOL of CHF patients at a specialized hospital in Bangladesh.

\subsection{Study Participants}

The participants were all Chronic Heart Failure patients admitted at a Specialized Hospital "National Institute of Cardiovascular Disease and Hospital", Shere-Bangla Nagar, Dhaka, Bangladesh. Average 777 patients receive their treatment from the hospital every day and average daily admitted patients were 197. This hospital was selected because about 200 beds are there in the Medicine ward, where around 500 chronic heart failure patients have been admitted monthly. Permission was obtained from the Director of the selected hospital through written order to collect the data.

Inclusion criteria:

1) Patients, who were diagnosed with chronic heart failure.

2) Patients, who were willing to participate, and aged over 18 years

3) Patients, who were able to read, speak, write and understand Bengali language.

Exclusion Criteria:

1) Patients with a documented history of psychiatric illness.

2) Patients who had a diagnosis of other life-threatening diseases (e.g. cancer). Sample size

One hundred and forty two chronic heart failure patients were recruited from the selected specialized hospital of Bangladesh. The required sample size was calculated by G-Power software (Version 3.1.2) using an F test (Linear multiple regressions: fixed model $\mathrm{R}^{2}$ deviation from zero). Statistical parameters are set as follows: $\alpha=$ 0.05 , small effect size $(\mathfrak{f} 2)=0.15$, power $(1-\beta)=0.95$, number of predictors $=16$ [19]. The calculated sample size was 107 . To reduce the attrition rate, $20 \%$ more 
subjects were added. Therefore, the final sample size was 142 in this study.

\subsection{Instruments}

Study variables included general characteristics of chronic heart failure patients, disease related characteristics, and disease related quality of life and general quality of life. Survey comprises four sections with previously validated 85 items explained in details below.

\subsubsection{General Characteristics of the Participants (See Appendix 1.1)}

Patients' general characteristics were measured using a 14-items socio-demographic questionnaire. This questionnaire contained age, gender, religion, marital status, monthly income, educational level, job status, residence, smoking habit, history of heart disease, exercise, sodium intake and height and weight.

\subsubsection{Disease Related Characteristics (See Appendix 1.2)}

Disease related characteristics has been subdivided into three, including: 1) NYHA stage of heart failure and classification system (see Appendix 1.2.1), 2) co-morbidity (see Appendix 1.2.2), 3) medication (see Appendix 1.2.3).

\subsubsection{NYHA Classification Questionnaire}

Previously validated 4-items of NYHA Functional Classification questionnaire was used to identify the patients' health status. The New York Heart Association (NYHA) functional class was categorized into four classification system of physical functioning which was ranged from I no symptoms that have an impact on ordinary daily activities to IV symptoms occur at rest [20].

\subsubsection{Co-Morbidity Related Questionnaire}

Heart failure patients' co-morbidities were identified by using 15 -items the Charlson Co morbidity Index (CCI) [21]. The CCI was developed to assess the number and the seriousness of co-morbidities that may affect the risk of mortality. It is a summative scale which yields a score ranging from 1 only heart failure presents to 30 extensive co-morbidity. The inter-rater reliability of CCI and the intra-class correlation co-efficient of the questionnaire was yielded at chronbach's alpha value of 0.67 and 0.93 respectively [22]. The internal consistency and reliability of this questionnaire was yielded at the chronbach's alpha value of 0.71 in the current study.

\subsubsection{Quality of Life of Chronic Heart Failure Patients}

Quality of Life of Chronic Heart Failure Patients has been divided into two categories:

1) Disease Related Quality of Life and 2) General Quality of Life.

a) Disease Related Quality of Life of chronic heart failure patients (see Appendix 1.3)

Quality of Life of Chronic Heart Failure Patients is defined as "a person's abstract impression of the impacts of a clinical condition or its treatment on his/ 
her everyday life" [23]. A Quality of life of chronic heart failure patients was measured by a21-item previously validated, the Minnesota Living with Heart Failure Questionnaire (MLHQOL). This scale was proposed in 1986 by the University of Minnesota consists of 21 questions asking about how much the disease and its treatment had affected the patient's life in the last month. Respondents were asked to answer each question which was ranged from 0 no effect to 5 very much. A higher score indicated a worsen QOL. This questionnaire was subcategorized into two domains including the physical state of the patients (16 Items) and the mental state of the patients (5 items). The score of physical domain was ranged from $0-80$, and the score of the mental state of the patients was ranged from 0 - 25. The total score of disease related quality of life was ranged from 0 105. Higher score indicated worsen quality of life of chronic heart failure patients. The internal consistency and reliabilities of the MLHFQ questionnaire was yielded at chronbach's alpha value of 0.88 and 0.93 respectively [24]. The internal consistency and reliability of MLHFQ questionnaire was yielded at the chronbach's alpha of 0.80 in the current study.

b) General Quality of Life of Chronic Heart Failure Patient (see Appendix 1.4)

General Quality of Life of Chronic Heart Failure Patientsis defined as "a fairly broad, multidimensional concept that includes symptoms of disease or health condition, treatment side effects, and functional status across physical, social and mental health life domains" [23]. Heart failure patients' general quality of life was measured by using the 26 items with previously validated World Health Organization Quality of Life (WHOQOL-BREF), which is a shorter version of the original instrument (WHOQOL-100). The instrument was subcategorized into physical health (7) psychological health (6), social relationships (3), environmental QOL (8) and total QOL (2). The items were rated on a 5 points Likert scale, and a higher score indicated better QOL. The internal consistency and reliability of the WHOQOL-BREF was yielded at chronbach's alpha value of 0.90 which showed high reliability [25]. The internal consistency and reliability of this instrument was yielded at Chronbach's alpha value of 0.73 in the current study.

Generally the disease related quality of life of chronic heart failure patient meant chronic heart failure patients live with the disease symptoms and is unable to do the normal daily living activities. So, their quality of life always become low level. Conversely general quality of life of chronic heart failure patients is well adherent to the treatment and are able to cope with the disease.

\subsubsection{Translation Process of the Instruments}

The translation-back translation technique was conducted by two bi-lingual translators. The first translator had translated the English version questionnaires into Bengali language. The second translator then translated the questionnaires from Bengali version back into English Language. Next, the two English versions of the questionnaires had been checked for clarity, discrepancy by the advisory committee who was expertise in heart failure management area from National Institute of Advanced Nursing Education and Research (NIANER), Dhaka, Ban- 
gladesh. The content equivalence of the items was also being checked by means of reconciling and evaluations performed by the translation team and health professionals.

\subsection{Data Collection}

Data were collected from 142 heart failure patients admitted in the National Institute of Cardiovascular Diseases and Hospital in Dhaka and data collection period was from January to February, 2019. Prior to data collection, the study was approved by the BangoBandhu Sheikh Mujib Medical University Institutional Review Board and National Institute of Advanced Nursing Education and Research Institutional Review Board (IRB NO. Exp. NIA-S-2018-09) in Bangladesh. Researcher communicated with the patient with the help of Cardiologist and Nurses. Approximately 500 admitted patients were approached for data collection. Of 500, around 142 patients were agreed to participant in the study. With the approval and a letter of permission from the Director of the National Institute of Advanced Nursing Education and Research, (NIANER), Dhaka, the researcher asked for permission from the concern Authorities of the respected hospital through Directorate General of Nursing and Midwifery in Dhaka, Bangladesh. Researcher communicated with Professor of cardiology unit, nursing superintendents and charge nurses on the selected wards of the targeted hospital to meet with the study patients. Then researcher briefly introduced about the purpose of the study to the heart failure patients. The patients who were interested to participate in the study were invited to face-to-face interview conducted by the researchers. Participants were needed approximately 30 minutes to complete the questionnaire. A total of 142 respondents completed the interview were considered to be consent to participate. Their participation was completely voluntary and anonymity was guaranteed. Patients could be stopped or withdrawn their participation from the study at any time without any reason or penalty if they wish to, with no risk to their hospital, personal or treatment procedure. All necessary information collected from the subjects were kept confidential and placed in secure locked cabinet for three years and this would be destroyed after completion of the study.

\section{Protection of Human Subjects}

A waiver of consent was granted because this is a survey research. No risks were incurred and no identifiable information or sensitive question was asked to answer. Before data collection, written consent was taken from participants and asked not to include any identifiable information on the survey. Structured questionnaire was used to collect data through face-to-face interview. All patients were ensured that their participation would be voluntary. Approximately $30 \mathrm{mi}$ nutes was required to fill-up the questionnaires.

The subjects' confidentiality and anonymity was strictly maintained with code numbers. Subjects were allowed to withdrawn at any time without any reason. Subjects were informed that the findings of the study would be submitted to 
scientific journal for publication and presented at conferences. Surveys and code sheets would be secured in a locked file accessible only to the investigator. All necessary information collected from the subjects would be kept confidential and destroyed after completion of the study.

\subsection{Data Analysis}

The data were analyzed using SPSS version 21.0 (SPSS Inc., Chicago, IL, USA). Descriptive statistics were used to summarize general characteristics of the patients, disease related characteristics, medication adherence of the patients, and disease related quality of life and general quality of life of heart failure patients. Associations between influencing factors and quality of life of patients were examined using independent sample $t$-tests and one way analyses of variance (ANOVA), with Schéffe post-hoc tests. Pearson correlation analysis was performed to explore the relationship between continuous variables. A value of $\mathrm{p}=$ 0.05 was considered statistically significant.

\section{Results}

Results are presented under the following headings.

\subsection{Socio-Demographic Characteristics of Participants}

One hundred and forty two chronic heart failure patients were participated in the face-to-face interview sessions. Fourteen (14) questions were asked to collect the participants' general characteristics. Among 142 patients (see Table 1) the mean age of participants was 58.74 years $(\mathrm{SD}=12.27)$. Majority $(85.9 \%)$ of the patients were male. Most of the patients (85.9\%) were Muslim and married (97.2\%) respectively. In terms of education, majority of the patients $(70.4 \%)$ had held primary education, $12 \%$ patients had held secondary education, and very few patients had held higher secondary education. On the other hand, very few (2.8\%) patients had held master degree. Considering occupation, above one third (37.3\%) of the patients was Housewives or Farmer, and quarter (24.6\%) of the patients was Businessman. The mean family income of the patients was $20,302.82$ taka ( $S D=12,306.94)$ and most $(69.7 \%)$ of the patients' monthly family income was around 20,000 taka. The patients mostly (81\%) lived in rural area. The mean BMI of the patients was calculated as $22.56(\mathrm{SD}=4.31)$ and most of their $(57.7 \%)$ BMI was at low level $(<23)$. In contrast, quarter of the patients' BMI was at high level (>25). Majority patients (89.4\%) did not perform regular exercise. Most of the patients (55.6\%) took high sodium. Majority of the patients (72.5\%) were past smoker. According to disease condition, above one third (35.2\%) of the patients had a family history of heart disease.

\subsection{Disease Related Characteristics of the Participants}

Twenty four (24) questions were used to collect data on the patients disease related characteristics. 
Table 1. Socio-demographic characteristics of participants $(\mathrm{N}=142)$.

\begin{tabular}{|c|c|c|c|c|}
\hline Variable & Category & $\mathrm{N}$ & $\%$ & $\mathrm{M}(\mathrm{SD})$ \\
\hline Age (Year) & & & & $58.74(12.27)$ \\
\hline \multirow[t]{2}{*}{ Gender } & Male & 122 & 85.9 & \\
\hline & Female & 20 & 14.1 & \\
\hline \multirow[t]{2}{*}{ Religion } & Islam & 133 & 93.7 & \\
\hline & Hinduism & 9 & 6.3 & \\
\hline \multirow[t]{3}{*}{ Marital Status } & Single & 3 & 2.1 & \\
\hline & Married & 138 & 97.2 & \\
\hline & Widowed & 1 & 0.7 & \\
\hline \multirow[t]{5}{*}{ Education } & Primary & 100 & 70.4 & \\
\hline & Secondary & 17 & 12.0 & \\
\hline & Higher Secondary & 12 & 8.5 & \\
\hline & Bachelor & 9 & 6.3 & \\
\hline & Masters & 4 & 2.8 & \\
\hline \multirow[t]{3}{*}{ Monthly Income } & $<20,302.82$ & 99 & 69.7 & $20,302.82(12,306.94)$ \\
\hline & $21,000-40,000$ & 34 & 23.9 & \\
\hline & $>40,000$ & 9 & 6.3 & \\
\hline \multirow[t]{3}{*}{ BMI } & $<23$ & 82 & 57.7 & $22.56(4.31)$ \\
\hline & $23-24.9$ & 25 & 17.6 & \\
\hline & $>25$ & 35 & 24.6 & \\
\hline \multirow[t]{5}{*}{ Job status } & Employee & 26 & 18.3 & \\
\hline & Housewife/Farmer & 53 & 37.3 & \\
\hline & Retired & 8 & 5.6 & \\
\hline & Business & 35 & 24.6 & \\
\hline & Others & 20 & 14.1 & \\
\hline \multirow[t]{2}{*}{ Residence } & Urban & 27 & 19.0 & $1.81(0.39)$ \\
\hline & Rural & 115 & 81.0 & \\
\hline \multirow[t]{3}{*}{ Smoking } & Never & 32 & 22.5 & \\
\hline & Past & 103 & 72.5 & \\
\hline & Current & 7 & 4.9 & \\
\hline \multirow[t]{3}{*}{ Family History of Heart Disease } & Yes & 50 & 35.2 & \\
\hline & No & 65 & 45.8 & \\
\hline & Unknowing & 27 & 19.0 & \\
\hline \multirow[t]{2}{*}{ Exercise (Year) } & Not exercise & 127 & 89.4 & \\
\hline & Do exercise & 15 & 10.6 & \\
\hline \multirow[t]{2}{*}{ Sodium Intake } & No & 63 & 44.4 & \\
\hline & Yes & 79 & 55.6 & \\
\hline
\end{tabular}


Disease related characteristics of the chronic heart failure patients were measured using Heart Failure Stage and Functional Class developed by New York Heart Association (NYHA) classification system; Charlson's Co-morbidity Index and medication (see Table 2). Based on NYHA classification, Class I means mild heart failure with ordinary physical activity which does not cause undue fatigue, palpitation, dyspnea or angina pain. Class II also means mild heart failure meaning that they are comfortable at rest. Ordinary physical activity results in fatigue, dyspnea, palpitation, or angina pain. Class III means moderate heart failure meaning that they are comfortable at rest. Less than ordinary physical activity results in fatigue, palpitation, and dyspnea or angina pain. Class IV means severe heart failure meaning that an inability to carry on physical activity without any discomfort, heart failure or angina syndrome may be present. According to findings, the majority (90.8\%) of the participants were classified as NYHA III and IV. Very few (4.2\%) patients were classified as NYHA class II. Majority (98.6\%) of the patients had co-morbid disease conditions. Most of the participants were prescribed a number of medication $(\mathrm{M}=5.78, \mathrm{SD}=0.87)$ especially Anticoagulants (98.6\%), Diuretics (98.6\%), Lipid lowering drugs (97.9\%), Beta-blocker (88\%), Calcium channel blocker (86.6\%), and ACE-I (85.9\%).

Table 2. Disease related Characteristics of the Participants $(\mathrm{N}=142)$.

\begin{tabular}{|c|c|c|c|c|}
\hline \multirow{2}{*}{ Variables } & \multirow{2}{*}{ Category } & \multicolumn{2}{|c|}{ Yes } & \multirow{2}{*}{$\mathrm{M} / \mathrm{SD}$} \\
\hline & & $\mathrm{N}$ & $\%$ & \\
\hline \multirow{3}{*}{ NYHA } & I & 7 & 4.9 & \multirow{3}{*}{$2.86(0.470)$} \\
\hline & II & 6 & 4.2 & \\
\hline & $\mathrm{III}+\mathrm{IV}$ & 129 & 90.8 & \\
\hline \multirow{3}{*}{$\mathrm{CCI}$} & $1-2$ & 2 & 1.4 & \multirow{3}{*}{$7.35(1.14)$} \\
\hline & & & & \\
\hline & $>3$ & 140 & 98.6 & \\
\hline \multirow{9}{*}{ Medication } & ACE-I & 122 & 85.9 & \multirow{9}{*}{$5.78(0.87)$} \\
\hline & Beta blockers & 125 & 88.0 & \\
\hline & Anticoagulants & 140 & 98.6 & \\
\hline & Diuretics & 140 & 98.6 & \\
\hline & & & & \\
\hline & $\mathrm{A}_{2}$ receptor blockers & 14 & 9.9 & \\
\hline & Calcium channel blocker & 123 & 86.6 & \\
\hline & Lanoxin & 18 & 12.7 & \\
\hline & Lipid lowering drugs & 139 & 97.9 & \\
\hline
\end{tabular}

NYHA: New York Heart Association. 


\subsection{Quality of Life of Chronic Heart Failure Patients}

Quality of life of chronic heart failure patient has been divided into two categories:

1) Disease Related Quality of Life and 2) General Quality of Life.

\subsubsection{Disease Related Quality of Life of Chronic Heart Failure Patients}

A previously validated 21 -items MLHFQ was used to measure the disease related quality of life of chronic heart failure patients.

Table 3 represents the distribution of frequency and percentage of disease related quality of life of CHF patients. According to findings, it shows that the mean of the total MLHFQ was at 94.16 (SD = 3.20) out of maximum of 105 point which was considered to be as high score of disease related QOL. Higher score indicates worse disease related quality of life of heart failure patients. In terms of item analysis, it shows that all CHF patients had difficulty in working around the house or yard, difficulty in going away from home or places, difficulty in doing things with their friends and family, difficulty in short of breath. However all patients were tired, fatigue and low on energy. All of the patients stayed in a hospital and all of their medical cost was high. All patients were worried and depressed. However, majority of the CHF patients (98.6\%) had sat or lie down to rest during the day leg and most of them (96.5\%) had difficulty in walking or climbing stairs. Huge number of patients (92.3\%) had difficulty in working to earn. Above half (62.7\%) of the CHF patients had swelling in ankles or legs and most of them (71.8\%) had difficulty in sleeping at night. More than half of the patients (64.1\%) ate less of the foods. Above half of them (62.7\%) experienced side effect of the treatment and same percentage of the patients felt a loss of self-control in their life.

\subsubsection{General Quality of Life of Chronic Heart Failure Patients}

General quality of life of chronic heart failure patients was measured by using a previously validated 26-item WHOQOL-BREF tool with 5-point Likert scale. Lower score indicated low quality of life of chronic heart failure patients. Higher score indicates better quality of life. Table 4 shows the distribution of frequency, percentage, mean and SD of General QOL of CHF patients. The results shows that the mean WHOQOL-BREF score was calculated as 41.05 ( $\mathrm{SD}=5.109)$ out of maximum of 130 points. It means that Chronic Heart Failure Patients' general quality of life was at low level. It indicates worsen general quality of life of CHF. All the sub-dimensions of WHOQOL-BREF scale also shows low level of general quality of life. Those included as Overall $(\mathrm{M}=1.24, \mathrm{SD}=0.25)$, Physical $(\mathrm{M}=$ $1.39, \mathrm{SD}=0.19)$, Psychological $(\mathrm{M}=1.76, \mathrm{SD}=0.37)$, Social $(\mathrm{M}=1.23, \mathrm{SD}=$ $0.17)$ and Environmental $(M=1.81, S D=0.29)$. According to item analysis, it shows that majority of the patients' $(74.6 \%)$ quality of life was very poor. However most of the patients (76.1\%) were dissatisfied with their health. All CHF patients had severe physical pain or problem that prevented them from doing what they would have needed to do. All of the patients needed constant medical 
Table 3. Disease related quality of life of chronic heart failure patients $(\mathrm{N}=142)$.

\begin{tabular}{|c|c|c|c|c|c|c|c|c|}
\hline \multirow{2}{*}{\multicolumn{2}{|c|}{ Items }} & $\begin{array}{c}\text { Not } \\
\text { applicable }\end{array}$ & Not at all & A little & $\begin{array}{l}\text { Moderate } \\
\text { amount }\end{array}$ & Very much & Extremely & \multirow{2}{*}{$\mathrm{M} \pm \mathrm{SD}$} \\
\hline & & $\mathrm{N}(\%)$ & $\mathrm{N}(\%)$ & $\mathrm{N}(\%)$ & $\mathrm{N}(\%)$ & $\mathrm{N}(\%)$ & $\mathrm{N}(\%)$ & \\
\hline 1 & $\begin{array}{l}\text { Causing swelling in your } \\
\text { ankles or legs? }\end{array}$ & & $5(3.5)$ & $14(9.9)$ & $15(10.6)$ & $89(62.7)$ & $19(13.4)$ & $4.08 \pm 0.59$ \\
\hline 2 & $\begin{array}{l}\text { Making you sit or lie down to } \\
\text { rest during the day? }\end{array}$ & & & & & $2(1.4)$ & $140(98.6)$ & $4.99 \pm 0.11$ \\
\hline 3 & $\begin{array}{l}\text { Making your walking about or } \\
\text { climbing stairs difficult? }\end{array}$ & & & & $4(2.8)$ & $1(0.7)$ & $137(96.5)$ & $4.94 \pm 0.34$ \\
\hline 4 & $\begin{array}{l}\text { Making your working around } \\
\text { the house or yard difficult? }\end{array}$ & & & & & & $142(100)$ & $5.00 \pm 0.00$ \\
\hline 5 & $\begin{array}{l}\text { Making your going places away } \\
\text { from home difficult? }\end{array}$ & & & & & & $142(100)$ & $5.00 \pm 0.00$ \\
\hline 6 & $\begin{array}{l}\text { Making your sleeping well } \\
\text { at night difficult? }\end{array}$ & & & & & $102(71.8)$ & $40(28.2)$ & $4.28 \pm 0.45$ \\
\hline 7 & $\begin{array}{l}\text { Making your relating to or doing things } \\
\text { with your friends or family difficult? }\end{array}$ & & & & & & $142(100)$ & $5.00 \pm 0.00$ \\
\hline 8 & $\begin{array}{l}\text { Making your working to } \\
\text { earn a living difficult? }\end{array}$ & & & & & $11(7.7)$ & $131(92.3)$ & $4.92 \pm 0.26$ \\
\hline 9 & $\begin{array}{l}\text { Making your recreational past times, } \\
\text { sports or hobbies difficult? }\end{array}$ & & & & & $66(46.5)$ & $76(53.5)$ & $4.54 \pm 0.50$ \\
\hline 10 & $\begin{array}{l}\text { Making you eat less of } \\
\text { the foods you like? }\end{array}$ & & & & $20(14.1)$ & $91(64.1)$ & $31(21.8)$ & $4.08 \pm 0.59$ \\
\hline 11 & Making you short of breath? & & & & & & $142(100)$ & $5.00 \pm 0.00$ \\
\hline 12 & $\begin{array}{l}\text { Making you tired, fatigued, } \\
\text { or low on energy? }\end{array}$ & & & & & & $142(100)$ & $5.00 \pm 0.00$ \\
\hline 13 & Making you stay on a hospital? & & & & & & $142(100)$ & $5.00 \pm 0.00$ \\
\hline 14 & Costing you money for medical care? & & & & & & $142(100)$ & $5.00 \pm 0.00$ \\
\hline 15 & Giving you side effects from treatments? & & & $1(.7)$ & $12(8.5)$ & $89(62.7)$ & $40(28.2)$ & $4.18 \pm 0.60$ \\
\hline 16 & Making your sexual activities difficult? & & & $6(4.2)$ & $81(57.0)$ & $36(25.4)$ & $19(1.4)$ & $3.48 \pm 0.77$ \\
\hline 17 & $\begin{array}{l}\text { Making you feel you are a } \\
\text { burden to your family? }\end{array}$ & & $1(0.7)$ & $48(33.8)$ & $36(25.4)$ & $39(27.5)$ & $18(12.7)$ & $3.18 \pm 1.06$ \\
\hline 18 & $\begin{array}{l}\text { Making you feel a loss of } \\
\text { self-control in your life. }\end{array}$ & & & & $35(24.6)$ & $89(62.7)$ & $18(12.7)$ & $3.88 \pm 0.60$ \\
\hline 19 & Making you worry? & & & & & & $142(100)$ & $5.00 \pm 0.00$ \\
\hline 20 & $\begin{array}{l}\text { Making it difficult for you to } \\
\text { concentrate or remember things? }\end{array}$ & & & $29(20.4)$ & $87(61.3)$ & $26(18.3)$ & & $2.98 \pm 0.62$ \\
\hline \multirow[t]{2}{*}{21} & Making you feel depressed? & & & & & & $142(100)$ & $5.00 \pm 0.00$ \\
\hline & & & & & & & Total & $94.1 \pm 3.20$ \\
\hline
\end{tabular}


Table 4. General quality of life of chronic heart failure patients $(\mathrm{N}=142)$.

\begin{tabular}{|c|c|c|c|c|c|c|c|}
\hline & \multirow[t]{2}{*}{ Items } & Very poor & Poor & $\begin{array}{l}\text { Neither poor } \\
\text { nor good }\end{array}$ & Good & Very good & \multirow[t]{2}{*}{$\mathrm{M} \pm \mathrm{SD}$} \\
\hline & & $\mathrm{N}(\%)$ & $\mathrm{N}(\%)$ & $\mathrm{N}(\%)$ & $\mathrm{N}(\%)$ & $\mathrm{N}(\%)$ & \\
\hline 1 & How would you rate your quality of life? & $106(74.6)$ & $36(25.4)$ & & & & $1.25 \pm 0.43$ \\
\hline 2 & How satisfied are you with your health? & $108(76.1)$ & $34(23.9)$ & & & & $1.24 \pm 0.42$ \\
\hline 3 & $\begin{array}{c}\text { To what extend do you feel that physical pain/problem } \\
\text { prevents you from doing what you need to do? }\end{array}$ & $142(100)$ & & & & & $1.00 \pm 0.00$ \\
\hline 4 & $\begin{array}{l}\text { How much do you need any medical treatment } \\
\text { to function in your daily life? }\end{array}$ & $142(100)$ & & & & & $1.00 \pm 0.00$ \\
\hline 5 & How much do you enjoy life? & $110(77.5)$ & $32(22.5)$ & & & & $1.23 \pm 0.41$ \\
\hline 6 & To what extent do you feel your life to be meaningful? & $114(80.3)$ & $28(19.7)$ & & & & $1.20 \pm 0.39$ \\
\hline 7 & How well are you able to concentrate? & $59(41.5)$ & $71(50.0)$ & $11(7.7)$ & $1(.7)$ & & $1.68 \pm 0.64$ \\
\hline 8 & How safe do you feel in your daily life? & $80(56.3)$ & $50(35.2)$ & $12(8.5)$ & & & $1.52 \pm 0.64$ \\
\hline 9 & How healthy is your physical environment? & $20(14.1)$ & $87(61.3)$ & $28(19.7)$ & $7(4.9)$ & & $2.15 \pm 0.71$ \\
\hline 10 & Do you have enough energy for everyday life? & $77(54.2)$ & $65(45.8)$ & & & & $1.46 \pm 0.50$ \\
\hline 11 & Are you able to accept your bodily appearance? & $72(50.7)$ & $70(49.3)$ & & & & $1.49 \pm 0.50$ \\
\hline 12 & Have you enough money to meet your needs? & $38(26.8)$ & $66(46.5)$ & $31(21.8)$ & $7(4.9)$ & & $2.05 \pm 0.82$ \\
\hline 13 & $\begin{array}{c}\text { How available to you is the information that } \\
\text { you need in our day-to-day life? }\end{array}$ & $40(28.2)$ & $62(43.7)$ & $40(28.2)$ & & & $2.00 \pm 0.75$ \\
\hline 14 & $\begin{array}{l}\text { To what extent do you have the } \\
\text { opportunity for leisure? }\end{array}$ & $31(21.8)$ & $83(58.5)$ & $28(19.7)$ & & & $1.98 \pm 0.64$ \\
\hline 15 & How well are you able to get around? & $68(47.9)$ & $62(43.7)$ & $12(8.5)$ & & & $1.61 \pm 0.64$ \\
\hline 16 & How satisfied are you with your sleep? & $49(34.5)$ & $93(65.5)$ & & & & $1.65 \pm 0.477$ \\
\hline 17 & $\begin{array}{l}\text { How satisfied are you with your ability to } \\
\text { perform your daily living activities? }\end{array}$ & $138(97.2)$ & $4(2.4)$ & & & & $1.03 \pm 0.16$ \\
\hline 18 & How satisfied are you with your capacity for work? & $138(97.2)$ & $4(2.8)$ & & & & $1.03 \pm 0.166$ \\
\hline 19 & How satisfied are you with yourself? & $70(49.3)$ & $72(50.7)$ & & & & $1.51 \pm 0.50$ \\
\hline 20 & How satisfied are you with your personal relationship? & $53(37.3)$ & $89(62.7)$ & & & & $1.63 \pm 0.48$ \\
\hline 21 & How satisfied are you with your sex life? & $37(26.1)$ & $79(55.6)$ & $24(16.9)$ & $2(1.4)$ & & $1.94 \pm 0.69$ \\
\hline 22 & $\begin{array}{c}\text { How satisfied are you with the support } \\
\text { you get from your friends? }\end{array}$ & $127(89.4)$ & $15(10.6)$ & & & & $2.11 \pm 0.30$ \\
\hline 23 & $\begin{array}{l}\text { How satisfied are you with the conditions } \\
\text { of your living place? }\end{array}$ & $31(21.8)$ & $60(42.3)$ & $42(29.6)$ & $9(6.3)$ & & $2.20 \pm 0.85$ \\
\hline 24 & How satisfied are you with your access to health services? & $33(23.2)$ & $67(47.2)$ & $34(23.9)$ & $8(5.6)$ & & $2.12 \pm 0.82$ \\
\hline 25 & How satisfied are you with your transport? & $22(15.5)$ & $106(74.6)$ & $8(5.6)$ & $6(4.2)$ & & $1.99 \pm 0.61$ \\
\hline \multirow[t]{2}{*}{26} & $\begin{array}{l}\text { How often do you have negative feelings such } \\
\text { as blue mood, despair, anxiety, depression? }\end{array}$ & & & & & $142(100)$ & $1.00 \pm 0.00$ \\
\hline & & Total & & & & & $41.05 \pm 5.10$ \\
\hline
\end{tabular}


treatment to function in their daily life. Most patients (65.5\%) were dissatisfied with their sleep. They experienced negative feelings such as blue mood, despair, anxiety, depression very frequently. However, majority of the CHF patients (97.2\%) had no ability to perform their daily living activities satisfactorily. The same percent was associated with no satisfaction with their capacity for work. Huge number $(89.4 \%)$ of patients was dissatisfied with their support they had got from their friends. Most (76.1\%) of the patients were very dissatisfied with their capacity for work, a large number (74.6\%) of patients rated their quality of life was very poor. Majority (80.3\%) of them felt that their life is not meaningful at all. Huge (77.5\%) number of them did not enjoy their life at all. A greater number $(74.6 \%)$ were dissatisfied with their transport. Above half of them (65.5\%) were dissatisfied with sleeping. More than half of the patients $(62.7 \%)$ were dissatisfied with their personal relationship and above half of them (58.5\%) had a little opportunity for leisure.

\subsection{Relationship between Demographic Characteristics and Disease Related QOL and General QOL of Chronic Heart Failure Patients}

Table 5 shows the relationship of the disease related QOL and general QOL with the Socio-demographic characteristics of the CHF patients. There is no significant difference between age and disease related QOL and general QOL. There is no significant difference between gender and disease related QOL of the patients but there is statistically significant differences between gender and general QOL $(\mathrm{t}=-2.451, \mathrm{P}=0.015)$. It means that female patients have better general QOL than male patients. In terms of Education there is significant difference within the patients those who had higher education than those who had little education $(t=-2.864, p=0.005)$. It indicates that the patients had better general QOL who had higher education than the little educated patients. The patients who had low monthly family income had very very significant differences with those who had high. It signify that the patients with low income status had lower QOL both in the general $(\mathrm{F}=8.096, \mathrm{P}=0.000)$ and disease $(\mathrm{F}=11.930, \mathrm{P}=0.000)$ related measures. There is a significant difference in QOL within the patients who lived in urban area $(t=2.068, p=0.040)$ than those of the rural area. It means that $\mathrm{QOL}$ is higher in the patients who lived in urban area than the rural area. The participants with low BMI exhibited low $(\mathrm{r}=0.171, \mathrm{p}=0.042)$ general QOL. There is also a significant difference between smoking status and general QOL of the patients $(t=3.138, p=0.002)$ meaning that $\mathrm{QOL}$ is lower in the patients with smoker than those of the non-smoker patients.

\subsection{Association between Disease Related Characteristics and Disease Related QOL and General QOL ( $=142)$}

Table 6 shows the association between Quality of life and NYHA heart failure functional class and co-morbidity related characteristics of the participants. The findings reveal that NYHA heart failure functional class was associated with 
Table 5. Relationship between demographic characteristics and both the disease related QOL and general QOL of chronic heart failure patients $(\mathrm{N}=142)$.

\begin{tabular}{|c|c|c|c|c|c|c|}
\hline \multirow{2}{*}{ Variable } & \multirow{2}{*}{ Category } & \multirow{2}{*}{$\mathrm{N}$} & \multicolumn{2}{|c|}{ Disease related QOL } & \multicolumn{2}{|c|}{ General QOL } \\
\hline & & & $\mathrm{M} \pm \mathrm{SD}$ & $\mathrm{t} / \mathrm{r} / \mathrm{F} / \mathrm{p}$ & $\mathrm{M} \pm \mathrm{SD}$ & $\mathrm{t} / \mathrm{r} / \mathrm{F} / \mathrm{p}$ \\
\hline \multirow[t]{2}{*}{ Age } & $<58$ & 59 & $4.50 \pm 0.15$ & $1.356(0.177)$ & $1.57 \pm 0.19$ & $-0.366(0.715)$ \\
\hline & $>58$ & 83 & $4.47 \pm 0.15$ & & $1.58 \pm 0.20$ & \\
\hline \multirow[t]{2}{*}{ Gender } & Male & 122 & $4.49 \pm 0.15$ & $1.149(0.253)$ & $1.56 \pm 0.19$ & $-2.451(0.015)$ \\
\hline & Female & 20 & $4.45 \pm 0.13$ & & $1.68 \pm 0.15$ & \\
\hline \multirow[t]{2}{*}{ Religion } & Islam & 133 & $4.489 \pm 0.15$ & $-0.380(0.705)$ & $1.58 \pm 0.19$ & $-0.306(0.760)$ \\
\hline & Others & 9 & $4.50 \pm 0.13$ & & $1.60 \pm 0.18$ & \\
\hline \multirow[t]{2}{*}{ Marital Status } & Married & 139 & $4.29 \pm 0.16$ & $-2.309(0.022)$ & $1.53 \pm 0.35$ & $-0.472(0.637)$ \\
\hline & Others & 3 & $4.49 \pm 0.15$ & & $1.58 \pm 0.19$ & \\
\hline \multirow[t]{2}{*}{ Education } & Few education & 117 & $4.449 \pm 0.15$ & $0.346(0.730)$ & $1.56 \pm 0.18$ & $-2.864(0.005)$ \\
\hline & Higher education & 25 & $4.47 \pm 0.16$ & & $1.68 \pm 0.21$ & \\
\hline \multirow[t]{3}{*}{ Monthly Income } & $<20,302.82$ & 99 & $4.46 \pm 0.13$ & $8.096(0.000)$ & $1.53 \pm 0.16$ & $11.930(0.000)$ \\
\hline & $21,000-40,000$ & 34 & $4.50 \pm 0.16$ & & $1.70 \pm 0.22$ & \\
\hline & $>40,000$ & 9 & $4.66 \pm 0.16$ & & $1.68 \pm 0.15$ & \\
\hline \multirow[t]{2}{*}{ Job status } & Employee & 26 & $4.49 \pm 0.07$ & $0.121(0.904)$ & $1.56 \pm 0.22$ & $-0.64(0.518)$ \\
\hline & Others & 116 & $4.48 \pm 0.16$ & & $1.58 \pm 0.19$ & \\
\hline \multirow[t]{2}{*}{ Residence } & Urban & 27 & $4.54 \pm 0.18$ & $2.068(0.040)$ & $1.63 \pm 0.20$ & $1.457(0.147)$ \\
\hline & Rural & 115 & $4.47 \pm 0.14$ & & $1.57 \pm 0.19$ & \\
\hline \multirow[t]{3}{*}{ BMI } & $<23$ & 82 & $4.49 \pm 0.16$ & $-0.134(0.874)$ & $1.56 \pm 0.18$ & $0.171(0.042)$ \\
\hline & $23-24.9$ & 25 & $4.48 \pm 0.15$ & & $1.54 \pm 0.17$ & \\
\hline & $>25$ & 35 & $4.47 \pm 0.12$ & & $1.65 \pm 0.22$ & \\
\hline \multirow[t]{2}{*}{ Smoking } & Non Smoker & 32 & $4.46 \pm 0.13$ & $-1.205(0.230)$ & $1.67 \pm 0.17$ & $3.138(0.002)$ \\
\hline & Smoker & 110 & $4.49 \pm 0.15$ & & $1.55 \pm 0.19$ & \\
\hline \multirow[t]{3}{*}{ Heart Disease history } & Yes & 50 & $4.46 \pm 0.14$ & $0.777(0.762)$ & $1.62 \pm 0.18$ & $2.059(0.131)$ \\
\hline & Unknowing & 27 & $4.48 \pm 0.16$ & & $1.54 \pm 0.15$ & \\
\hline & No & 65 & $4.50 \pm 0.15$ & 1.59 & $1.56 \pm 0.21$ & \\
\hline \multirow[t]{2}{*}{ Exercise } & Not exercise & 127 & $4.489 \pm 0.14$ & $-0.644(0.521)$ & $1.58 \pm 0.20$ & $-0.280(0.780)$ \\
\hline & Do exercise & 15 & $4.5 \pm 1.20$ & & $1.59 \pm 0.11$ & \\
\hline \multirow[t]{2}{*}{ Sodium Intake } & No & 63 & $4.50 \pm 0.16$ & $0.832(0.407)$ & $1.59 \pm 0.18$ & $0.822(0.412)$ \\
\hline & Yes & 79 & $4.47 \pm 0.14$ & & $1.57 \pm 0.20$ & \\
\hline
\end{tabular}


disease $(\mathrm{P}=0.003)$ related QOL. The poorer QOL was associated with the lower functional status. The disease related QOL Score was higher with presence of one or more co-morbidity. The general QOL score was lower with presence of one or more co-morbidity.

\subsection{Correlations between Chronic Heart Failure Patients' QOL and General QOL $(\mathrm{N}=142)$}

Pearson's Correlation between the total, physical and emotional dimensions of the WHOQOL-BREF and MLHFQ are shown in Table 7.

Results revealed that there is a positive correlation between MLHFQ Physical and MLHFQ Mental $(r=0.583, p=0.000)$ meaning that worsen Physical condition indicated the worsen mental condition. MLHFQ physical $(\mathrm{r}=0.893, \mathrm{p}=$ $0.000)$, and Mental $(r=0.886, p=0.000)$ were strongly positively correlated with total MLHFQ. It means that the worsen physical and mental condition of MLHFQ highly affected the total QOL of MLHFQ.

Physical $(r=0.298, \mathrm{p}=0.000)$ and psychological $(\mathrm{r}=0.509, \mathrm{p}=0.000)$ dimensions of WHOQOL-BREF were positively significantly correlated with total dimension of WHOQOL-BREF.

Table 6. Association between disease related characteristics and disease related QOL and general QOL $(\mathrm{N}=142)$.

\begin{tabular}{|c|c|c|c|c|c|c|}
\hline \multirow{2}{*}{ Variable } & \multirow{2}{*}{ Category } & \multirow{2}{*}{$\mathrm{N}$} & MLHFQ & WHOQOL-BREF & \multirow{2}{*}{$\mathrm{M} \pm \mathrm{SD}$} & \multirow{2}{*}{$\mathrm{t}, \mathrm{F}(\mathrm{p})$} \\
\hline & & & $\mathrm{M} \pm \mathrm{SD}$ & $\mathrm{t}, \mathrm{F}(\mathrm{p})$ & & \\
\hline \multicolumn{7}{|l|}{ NYHA Class } \\
\hline & I & 7 & $4.63 \pm 0.160$ & $6.084(0.003)$ & $1.59 \pm 0.086$ & $0.020(0.980)$ \\
\hline & II & 6 & $4.60 \pm 0.219$ & & $1.58 \pm 0.150$ & \\
\hline & III + IV & 129 & $4.47 \pm 0.143$ & & $1.58 \pm 0.203$ & \\
\hline \multicolumn{7}{|l|}{ CCI } \\
\hline & $1-2$ & 2 & $4.57 \pm 0.269$ & $0.816(0.416)$ & $1.65 \pm 0.107$ & $0.542(0.588)$ \\
\hline & $>3$ & 140 & $4.48 \pm 152$ & & $1.58 \pm 0.197$ & \\
\hline
\end{tabular}

Table 7. Correlations between diseases related QOL and general QOL $(\mathrm{N}=142)$.

\begin{tabular}{lccccc}
\hline \multicolumn{1}{c}{ Quality of Life Measurements } & 1 & 2 & 3 & 4 & 5 \\
\hline 1) MLHFQ, Physical & 1 & & & & \\
2) MLHFQ, Mental & $0.583(0.000)$ & 1 & & & \\
3) MLHFQ, Total & $0.893(0.000)$ & $0.886(0.000)$ & 1 & 1 & 1 \\
4) WHOQOL-BREF, Physical & $0.130(0.123)$ & $0.036(0.674)$ & $0.094(0.267)$ & $0.509(0.000)$ & $0.509(0.000)$ \\
5) WHOQOL BREF, Psychological & $-0.248(0.003)$ & $-0.180(0.032)$ & $-0.241(0.004)$ & 1 \\
6) WHOQOL-BREF, Total & $-0.044(0.604)$ & $0.074(0.380)$ & $0.016(0.850)$ & $0.298(0.000)$ & 0 \\
\hline
\end{tabular}


Dimensions of Physical $(r=-0.248, \mathrm{p}=0.000)$, mental $(\mathrm{r}=-0.180, \mathrm{p}=0.000)$ and total $(\mathrm{r}=-0.241, \mathrm{p}=0.000)$ of MLHFQ were significantly correlated with the psychological dimension of WHOQOL-BREF except total two dimensions of it.

Correlation is very significant at 0.01 level (2-tailed). Correlation is significant at the 0.05 level (2-tailed). Higher score in the MLHFQ represent worse QOL and lower score in the WHOQOL-BREF represent worse QOL.

\section{Discussion}

The study was carried out to identify the factors influencing the QOL of the Chronic Heart Failure patients with one hundred and forty two CHF patients at National Institute of Cardio-vascular Diseases and hospital. Findings reveals that sex, residence, monthly income, education, smoking status, marital status and NYHA heart failure classification have effect on the CHF patients' QOL.

The mean of the total CHF disease related QOL was $94.16(\mathrm{SD}=3.20)$ out of maximum of 105. This high score indicates worsen QOL of CHF patients. The finding of this current study is similar with the previous study in Serbia [28]. In Serbian study, the mean score of CHF disease related QOL was 50.4. Although cultural context, educational background and economic status were different between Serbia and Bangladesh, poor QOL of CHF patient was found between the countries. This might be due to life style, age, sex, and income or unaware of risk factors for developing CHF. However result is opposite to Korean study. In Korean study the aim was to identify the factors affecting HRQL in Korean patient with CHF using two health related QOL measurements. Study found that CHF disease related QOL was at low level which indicated better able to differentiate sex, co-morbidity and functional status. This dissimilar finding could be due to higher educational status, more health awareness about CHF and high economic status of the heart failure patient in Korea [9].

The mean score of general QOL of CHF patients was calculated as 41.05 (SD = 5.109 ) out of maximum of 130 which indicates low level of general quality QOL of CHF patients. The result of this study is consistent with the Korean study. In Korean study the mean score of general QOL of CHF patient was at low which indicates very worsen general QOL [9].

In the present study monthly income was identified as one of the major factor associated with QOL, which is similar to the Serbian study. The financial difficulties negatively affect HRQOL which might be due to loss of their jobs and increases in medication expenses because of HF or increase in life expectancy or increasing prevalence of heart failure in the aging population [26] [27].

Little education (70.4\%) was related to worsen general QOL. This is in accordance with the findings of the Serbian and Korean study, which has reported better physical QOL in highly educated patients [9] [28]. Education level and its close association with socio-economic status are predictive of reduced quality of life [29]. A possible explanation is that low financial sources along with inability 
to understand medical instructions imply lack of adherence to treatment and therefore, reduced effectiveness of disease management [29].

Living in rural area is related to the worsen disease related QOL of the CHF patients, which is differed from the study conducted in Attica [29]. Reduced total QOL was associated with living in country capital may be due to the stressful everyday living [29]. However rural patients might have limited access to health care services including cardiac rehabilitation interventions and are more likely to be readmitted due to the exacerbations of disease [29]. There was worsening general QOL score with male which is almost consistent with the findings of Korean study. Worsen disease related QOL was found among male. This is might be due to a lack of medication adherence or negligence to the prevention of primary disease symptoms, smoking, high salt intake or increase risk of cardiovascular diseases with male sex associated with family history. While other studies have reported worse HRQOL in women [26] due to low income, lower educational status or depression associated with the disease.

Marital status had influence on disease related QOL may be due to increasing age, excessive family burden, low socio-economic status, life style, depression which were differed from the results of the Korean study and another study found better HRQOL in married subjects [30] or who were living with spouse [28]. This dissimilarity might be due to differences in socio-demographic context, exchange of support between family members and others frequently, both providing and receiving [31] [32].

According to this study findings worsen QOL was associated with the NYHA heart failure functional class III and IV among the participants. This is consistent with Serbian study. This is may be because of CHF patients often experience loss of functional independence in daily activities such as feeding, dressing, housekeeping, bathing, and walking [29] and the most common symptoms affecting QOL are dyspnea at rest or on exertion, paroxysmal nocturnal dyspnea, and fatigue as well as lack of energy [29], which may be due to presence of multiple co-morbidities and side effects from medication or non-adherence to the treatment, or from the negligence of the primary symptoms. In contrast to Korean study, the majority (52.6\%) were classified as NYHA II. This is may be due to awareness about disease, higher education, efficient caregiver role or family support and improved health management system of the country [33].

Dimensions of Physical, mental and total of MLHFQ were significantly correlated with the psychological dimension of WHOQOL-BREF except total two dimensions of it, which is consistent with the Korean study where each dimension's scores on the WHOQOL-BREF was correlated with those of the MLHFQ. This may be because of the worsened physical condition affected mental health; worsen physical and mental condition of CHF patients which were highly affected towards total QOL.

The burden of $\mathrm{CHF}$ is expected to raise considerably due to the incidence of $\mathrm{CHF}$ increases two folds for each decades of life. Personal, economic and health 
care burden of $\mathrm{CHF}$ is expected to increase more in the future as life expectancy of people increases, placing further pressure on the finite health care resources [34]. Recently, the American Heart Association identified the following patient behaviors required for self-management of $\mathrm{CHF}$, adherence to prescribed medications, diet and exercise, symptom and weight monitoring, fluid and alcohol restrictions, cessation of smoking, informing their physician of any no prescribed medication they may be administrating, including complementary therapies, and incorporating preventive behaviors into their lifestyle [34] [35]. Recent systematic reviews suggested that the advanced practice registered nurse can provide a cost-effective alternative for labor-intense HF management [34] [36] [37].

However, to increase and improve nurses' roles, the author suggests that registered nurse should support the development and adaptation of a disease-management program for patients with $\mathrm{CHF}$ in Bangladesh and promote the centrality of nursing in these programs to reduce the economic burden of patients and improve their QOL [34].

\section{Conclusions}

The study found that total monthly income, functional status, education, residence, smoking, sex and NYHA class were greatly affected QOL of CHF. Obtaining an assessment of a patient's difficulty in affording health care may be important in uncovering potential explanations for low QOL. Further study needs to be conducted to eliminate healthcare disparities based on economic status and to facilitate cost-effective nursing intervention strategies for the patients with $\mathrm{CHF}$.

The current study has number of limitations, which should be noted. First, time limitation. Second, small sample size. Third, the study was conducted only in one setting in Bangladesh therefore; the current study result cannot be generalized to other settings.

\section{Recommendations}

Future study is indicated to measure the QOL of CHF patients in large scale. Developing cost effective strategy for life style modification and disease management program is useful to reduce and prevent factors influencing quality of life for the patients with chronic heart failure.

\section{Acknowledgements}

My sincere gratitude goes to Thesis Chair Dr. Md. Shariful Islam, whose constructive advices, clear explanations and clean cut instructions help me in completion of this dissertation. Special thanks extends to my Co-advisors Dr. Mohammad Nurul Anowar, for his enthusiastic involvement and assistance and Dr. Abdul Latif for his dedicated contribution and motivational guidelines. I appreciate the Professor of Emeritus Chung Yul Lee, Former Director, for her valuable 
assistance and suggestions.

I express my heartfelt gratitude to Mr. Dilip Thomas Rozario, who avails the opportunity for publishing. Off course, I must acknowledge to all Physicians, nurses, staffs and the patients, who helped and allowed me to collect the data. I express my profound gratitude to all my family members for their dedicated and relent less assistance.

Lastly, I would like to dedicate my dissertation to the memories of my parents (late). You are missed every moment.

\section{Conflicts of Interest}

The authors declare no conflicts of interest regarding the publication of this paper.

\section{References}

[1] Polikandrioti, M., Goudevenos, J., Michalis, L.K., Koutelekos, J., Kyristi, H., Tzialas, D. and Elisaf, M. (2015) Factors Associated with Depression and Anxiety of Hospitalized Patients with Heart Failure. Hellenic Journal of Cardiology, 56, 26-35.

[2] Yancy, C.W., Jessup, M., Bozkurt, B., Butler, J., Casey, D.E., Drazner, M.H., et al. (2013) ACCF/AHA Guideline for the Management of Heart Failure. Journal of the American College of Cardiology, 62, e147-e239. https://doi.org/10.1016/j.jacc.2013.05.019

[3] Health Bulletin (2016) The Data Belong to Jan-Dec 2015. National Institute of Cardiovascular Disease, Dhaka.

[4] Muhit, M.A., Rahman, M.O., Raihan, S.Z., Asaduzzaman, M., Akbar, M.A., Sharmin, N. and Faroque, A.B.M. (2012) Cardiovascular Disease Prevalence and Prescription Patterns at a Tertiary Level Hospital in Bangladesh. Journal of Applied Pharmaceutical Science, 2, 8.

[5] Savarese, G. and Lund, L.H. (2017) Global Public Health Burden of Heart Failure. Cardiac Failure Review, 3, 7. https://doi.org/10.15420/cfr.2016:25:2

[6] Seth, S., Ramakrishnan, S., Parekh, N., Karthikeyan, G., Singh, S. and Sharma, G. (2017) Heart Failure Guidelines for India: Update 2017. Journal of the Practice of Cardiovascular Sciences, 3, 133. https://doi.org/10.4103/jpcs.jpcs 118

[7] Ahmad, T., Munir, A., Bhatti, S.H., Aftab, M. and Raza, M.A. (2017) Survival Analysis of Heart Failure Patients: A Case Study. PLoS ONE, 12, e0181001. https://doi.org/10.1371/journal.pone.0181001

[8] Marques de Sousa, M., dos Santos Oliveira, J., Oliveira Soares, M.J.G., Amorim de Araújo, A. and dos Santos Oliveira, S.H. (2017) Quality of Life of Patients with Heart Failure: Integrative Review. Journal of Nursing UFPE, 11, 1289-1288.

[9] Chu, S.H., Lee, W.H., Yoo, J.S., Kim, S.S., Ko, I.S., Oh, E.G., Kang, S.M., et al. (2014) Factors Affecting Quality of Life in Korean Patients with Chronic Heart Failure. Japan Journal of Nursing Science, 11, 54-64. https://doi.org/10.1111/jjns.12002

[10] Bilbao, A., Escobar, A., García-Perez, L., Navarro, G. and Quirós, R. (2016) The Minnesota Living with Heart Failure Questionnaire: Comparison of Different Factor Structures. Health and Quality of Life Outcomes, 14, 23. https://doi.org/10.1186/s12955-016-0425-7

[11] Teovska Mitrevska, N., Eleftheriadou, V. and Guarneri, F. (2012) Quality of Life in Vitiligo Patients. Dermatologic Therapy, 25, S28-S31. 
https://doi.org/10.1111/dth.12007

[12] Chaturvedi, V., Parakh, N., Seth, S., Bhargava, B., Ramakrishnan, S., Roy, A., Anand, K., et al. (2016) Heart Failure in India: The INDUS (INDia Ukieri Study) Study. Journal of the Practice of Cardiovascular Sciences, 2, 28-35. https://doi.org/10.4103/2395-5414.182988

[13] Huffman, M.D. and Prabhakaran, D. (2010) Heart Failure: Epidemiology and Prevention in India. The National Medical Journal of India, 23, 283.

[14] AbuRuz, M.E., Alaloul, F., Saifan, A., Masa'Deh, R. and Abusalem, S. (2016) Quality of Life for Saudi Patients with Heart Failure: A Cross-Sectional Correlational Study. Global Journal of Health Science, 8, 49. https://doi.org/10.5539/gjhs.v8n3p49

[15] Chatterjee, N.A., Chae, C.U., Kim, E., Moorthy, M.V., Conen, D., Sandhu, R.K., Albert, C.M., et al. (2017) Modifiable Risk Factors for Incident Heart Failure in Atrial Fibrillation. JACC: Heart Failure, 5, 552-560. https://doi.org/10.1016/j.jchf.2017.04.004

[16] Kabiruzzaman, M., Malik, F.N., Ahmed, N., Badiuzzaman, M., Choudhury, S.R., Haque, T., Dutta, A.K., et al. (2010) Burden of Heart Failure Patients in a Tertiary Level Cardiac Hospital. Journal of Bangladesh College of Physicians \& Surgeons, 28, 24-29. https://doi.org/10.3329/jbcps.v28i1.4640

[17] Hwang, S.L., Liao, W.C. and Huang, T.Y. (2014) Predictors of Quality of Life in Patients with Heart Failure. Japan Journal of Nursing Science, 11, 290-298. https://doi.org/10.1111/jins.12034

[18] Braunwald, E. (2013) Research Advances in Heart Failure: A Compendium. Circulation Research, 113, 633-645. https://doi.org/10.1161/CIRCRESAHA.113.302254

[19] Faul, F., Erdfelder, E., Lang, A.-G. and Buchner, A. (2007) G*Power 3: A Flexible Statistical Power Analysis Program for the Social, Behavioral, and Biomedical Sciences. Behavior Research Methods, 39, 175-191. https://doi.org/10.3758/BF03193146

[20] Bennett, J.A., Riegel, B., Bittner, V. and Nichols, J. (2002) Validity and Reliability of the NYHA Classes for Measuring Research Outcomes in Patients with Cardiac Disease. Heart \& Lung, 31, 262-270. https://doi.org/10.1067/mhl.2002.124554

[21] Extermann, M. (2000) Measuring Comorbidity in Older Cancer Patients. European Journal of Cancer, 36, 453-471. https://doi.org/10.1016/S0959-8049(99)00319-6

[22] Hall, S.F., Groome, P.A., Streiner, D.L. and Rochon, P.A. (2006) Interrater Reliability of Measurements of Comorbidilness Should Be Reported. Journal of Clinical Epidemiology, 59, 926-933. https://doi.org/10.1016/j.jclinepi.2006.02.006

[23] US Department of Health and Human Services FDA Center (2006).

[24] Heo, S., Moser, D.K., Riegel, B., Hall, L.A. and Christman, N. (2005) Testing a Published Model of Health-Related Quality of Life in Heart Failure. Journal of Cardiac Failure, 11, 372-379. https://doi.org/10.1016/j.cardfail.2004.12.001

[25] Min, S.K., Lee, C.I., Kim, K.I., Suh, S.Y. and Kim, D.K. (2000) Development of Korean Version of WHO Quality of Life Scale Abbreviated Version (WHOQOLBREF). Journal of Korean Neuropsychiatric Association, 39, 571-579.

[26] Nesbitt, T., Doctorvaladan, S., Southard, J.A., Singh, S., Fekete, A., Marie, K., Cooper, L., et al. (2014) Correlates of Quality of Life in Rural Patients with Heart Failure. Circulation: Heart Failure, 7, 882-887. https://doi.org/10.1161/CIRCHEARTFAILURE.113.000577

[27] Heo, S., Lennie, T.A., Okoli, C. and Moser, D.K. (2009) Quality of Life in Patients with Heart Failure: Ask the Patients. Heart \& Lung, 38, 100-108. 
https://doi.org/10.1016/j.hrtlng.2008.04.002

[28] Erceg, P., Despotovic, N., Milosevic, D.P., Soldatovic, I., Zdravkovic, S., Tomic, S., Potic, B., et al. (2013) Health-Related Quality of Life in Elderly Patients Hospitalized with Chronic Heart Failure. Clinical Interventions in Aging, 8, 1539. https://doi.org/10.2147/CIA.S53305

[29] Audi, G., Korologou, A., Koutelekos, I., Vasilopoulos, G., Karakostas, K., Makrygianaki, K. and Polikandrioti, M. (2017) Factors Affecting Health Related Quality of Life in Hospitalized Patients with Heart Failure. Cardiology Research and Practice, 2017, Article ID: 4690458. https://doi.org/10.1155/2017/4690458

[30] Luttik, M.L., Jaarsma, T., Veeger, N. and van Veldhuisen, D.J. (2006) Marital Status, Quality of Life, and Clinical Outcome in Patients with Heart Failure. Heart \& Lung, 35, 3-8. https://doi.org/10.1016/j.hrtlng.2005.08.001

[31] Shahriari, M., Alimohammadi, N. and Ahmadi, M. (2016) Effects of a Family Centered Program on Perceived Social Support in Patients with Congestive Heart Failure: An Interventional Study. Journal of Education and Health Promotion, 5, 6. https://doi.org/10.4103/2277-9531.184559

[32] Dunbar, S.B., Clark, P.C., Quinn, C., Gary, R.A. and Kaslow, N.J. (2008) Family Influences on Heart Failure Self-Care and Outcomes. The Journal of Cardiovascular Nursing, 23, 258-265. https://doi.org/10.1097/01.JCN.0000305093.20012.b8

[33] Hwang, B., Fleischmann, K.E., Howie-Esquivel, J., Stotts, N.A. and Dracup, K. (2011) Caregiving for Patients with Heart Failure: Impact on Patients' Families. American Journal of Critical Care, 20, 431-442. https://doi.org/10.4037/ajcc2011472

[34] Azam, S.A. and Ullah, M. (2016) Heart Failure How Can We Face This Pandemic of Twenty First Century? Bangladesh Heart Journal, 31, 1-2. https://doi.org/10.3329/bhj.v31i1.30613

[35] Ditewig, J.B., Blok, H., Havers, J. and van Veenendaal, H. (2010) Effectiveness of SelfManagement Interventions on Mortality, Hospital Readmissions, Chronic Heart Failure Hospitalization Rate and Quality of Life in Patients with Chronic Heart Failure: A Systematic Review. Patient Education and Counseling, 78, 297-315. https://doi.org/10.1016/j.pec.2010.01.016

[36] Case, R., Haynes, D., Holaday, B. and Parker, V.G. (2010) Evidence-Based Nursing: The Role of the Advanced Practice Registered Nurse in the Management of Heart Failure Patients in the Outpatient Setting. Dimensions of Critical Care Nursing, 29, 57-62. https://doi.org/10.1097/DCC.0b013e3181c92efb

[37] Ho, Y.L., Hsu, T.P., Chen, C.P., Lee, C.Y., Lin, Y.H., Hsu, R.B., Ting, H.T., et al. (2007) Improved Cost-Effectiveness for Management of Chronic Heart Failure by Combined Home-Based Intervention with Clinical Nursing Specialists. Journal of the Formosan Medical Association, 106, 313-319.

https://doi.org/10.1016/S0929-6646(09)60258-8 


\section{Appendix 1: Questionnaire (English Version)}

Date

The questionnaire is divided into four sections. Section one consists of questions related to participants' Socio Demographic Questionnaire (SDQ-14), section two consists of Disease related Questionnaire (DRQ-24), section three consists of Minnesota Living with Heart Failure Questionnaire (MLHFQ-21) regarding the disease related QOL and section four consist of WHOQOL-BREF-questionnaire (26 items) related to general QOL of CHF patients.

\subsection{Section 1. Socio Demographic Questionnaire}

Instruction: Please fill up the blanks and put tick $(\sqrt{ })$ mark in the left side, which is appropriate for you.

1) What is your current age? ...............years.

2) What is your height? ...................cm

3) How much your weight? ................ gs

4) What is your sex?
a. Male
b. Female

5) What is your religion?
a. Islam
b. Hinduism
c. Buddhism
d. Christian
e. Others

6) Where is your living area?
a. Urban
b. Rural

7) What is your marital status?
a. Single
b. Married
c. Widowed
d. Divorced
e. Separated

8) What is your educational level?
a. Analphabet
b. Primary
c. Secondary
d. Higher secondary
e. Bachelor
f. Masters
g. Others

9) What is your job status?
a. Employee
b. Housewife/Farmer
c. Retired
d. Unemployed
e. Business
f. Others

10) What is your smoking status?
a. Never smoker
b. Past smoker
c. Current smoker

11) Do you have any history of heart disease in your family?
a. Yes
b. No
c. Do not know/unknowing

12) How many times do you exercise? /week.

13) What is the total monthly income of your family? .TK only.

14) Do you take low sodium?
a. Yes
b. No

\subsection{Section 2: Disease Related Questionnaire Is Subdivided Into Three Parts}

\subsubsection{Heart Failure Stages and Functional Classifications}

Class I (Mild): Ordinary physical activity does not cause undue fatigue, palpi- 
tation, dyspnea or angina pain.

Class II (Mild): They are comfortable at rest. Ordinary physical activity results in fatigue, palpitation, dyspnea, or angina pain.

Class III (Moderate): They are comfortable at rest. Less than ordinary activity causes fatigue, palpitation, dyspnea, or angina pain.

Class IV (Severe): inability to carry on any physical activity without discomfort heart failure or the angina syndrome may be present.

1.2.2. Factors Related to Co-Morbidity: Please Identify the Presence of Any Disease According to Charlson Co-Morbidity Index

1) What is your current age? years.
a. $<50$ years
b. 50 - 59 years
c. 60 - 69 years
d. 70 - 79 years
e. $>80$ years

Do you have the following disease?

2) Diabetes mellitus
a. None
b. Uncomplicated
c. End organ damage

3) Liver Disease
a. None
b. Mild
c. Moderate

4) Malignancy
a. None
b. Any Leukemia, lymphoma, or localized solid tumor
c. Metastatic solid tumor

5) Myocardial Infarction
a. No
b. Yes

6) $\mathrm{COPD}$
a. No
b. Yes

7) Peripheral Vascular Disease
a. No
b. Yes

8) CVA or TIA
a. No
b. Yes

9) Dementia
a. No
b. Yes

10) Hemiplegia
a. No
b. Yes

11) Connective tissue disease
a. No
b. Yes

12) Peptic ulcer disease
a. No
b. Yes

13) Acquired Immune Deficiency Syndromes (AIDS)
a. No
b. Yes

14) Chronic Kidney Disease
a. No
b. Yes

15) Chronic Heart Failure
a. No
b. Yes

\subsubsection{CHF Medications Adherence}

Instruction: Identify the Number of heart-related medications taken daily 
NB: Please put tick $(\sqrt{ })$ mark on the word of "yes" or "no" in following box which is more appropriate for.

\begin{tabular}{ccc}
\hline S/No. & Name of medication & Yes \\
\hline 1 & A2 receptor blockers & \\
2 & Beta blockers & \\
3 & Anticoagulants & \\
4 & ACE-I & \\
5 & Diuretics (>1) \\
6 & Calcium channel blocker \\
7 & Lanoxin (Digoxin) \\
8 & Lipid lowering drug \\
\hline
\end{tabular}

\subsection{Section 3: Consists of Minnesota Living with Heart Failure Questionnaire (MLHFQ-21) regarding CHF Related QOL Factors}

Factors related to CHF that affect patients' life during the past month (4 weeks). After each question, circle the $0,1,2,3,4$, or 5 to show how much your life was affected. If a question does not apply to you, circle the 0after that question.

Did your heart failure prevent you from living as you wanted during the past month (4 weeks) by

\begin{tabular}{|c|c|c|c|c|c|c|c|}
\hline 1 & Causing swelling in your ankles or legs? & 0 & 1 & 2 & 3 & 4 & 5 \\
\hline 2 & Making you sit or lie down to rest during the day? & 0 & 1 & 2 & 3 & 4 & 5 \\
\hline 3 & Making your walking about or climbing stairs difficult? & 0 & 1 & 2 & 3 & 4 & 5 \\
\hline 4 & Making your working around the house or yard difficult? & 0 & 1 & 2 & 3 & 4 & 5 \\
\hline 5 & Making your going places away from home difficult? & 0 & 1 & 2 & 3 & 4 & 5 \\
\hline 6 & Making your sleeping well at night difficult? & 0 & 1 & 2 & 3 & 4 & 5 \\
\hline 7 & $\begin{array}{l}\text { Making your relating to or doing things with } \\
\text { your friends or family difficult? }\end{array}$ & 0 & 1 & 2 & 3 & 4 & 5 \\
\hline 8 & Making your working to earn a living difficult? & 0 & 1 & 2 & 3 & 4 & 5 \\
\hline 9 & $\begin{array}{l}\text { Making your recreational past times, } \\
\text { sports or hobbies difficult? }\end{array}$ & 0 & 1 & 2 & 3 & 4 & 5 \\
\hline 10 & Making you eat less of the foods you like? & 0 & 1 & 2 & 3 & 4 & 5 \\
\hline 11 & Making you short of breath? & 0 & 1 & 2 & 3 & 4 & 5 \\
\hline 12 & Making you tired, fatigued, or low on energy? & 0 & 1 & 2 & 3 & 4 & 5 \\
\hline 13 & Making you stay on a hospital? & 0 & 1 & 2 & 3 & 4 & 5 \\
\hline 14 & Costing you money for medical care? & 0 & 1 & 2 & 3 & 4 & 5 \\
\hline 15 & Giving you side effects from treatments? & 0 & 1 & 2 & 3 & 4 & 5 \\
\hline
\end{tabular}




\begin{tabular}{llllllll}
\hline 16 & Making your sexual activities difficult? & 0 & 1 & 2 & 3 & 4 & 5 \\
17 & Making you feel you are a burden to your family? & 0 & 1 & 2 & 3 & 4 & 5 \\
18 & $\begin{array}{l}\text { Making you feel a loss of self-control in your life. } \\
\text { Making you worry }\end{array}$ & 0 & 1 & 2 & 3 & 4 & 5 \\
19 & 0 & 1 & 2 & 3 & 4 & 5 \\
20 & $\begin{array}{c}\text { Making it difficult for you to concentrate or } \\
\text { remember things? }\end{array}$ & 0 & 1 & 2 & 3 & 4 & 5 \\
21 & $\quad 0$ & 1 & 2 & 3 & 4 & 5 \\
\hline
\end{tabular}

\subsection{Section 4: WHOQOL-BREF Questionnaire Related to General QOL of CHF Patients}

The following question asks how you feel about your quality of life, health or other areas of your life. I will read out each question to you, along with the response options.

Instruction: Please choose the answer that appears most appropriate. If you are unsure about which response to give to a question, the first response you think of is often the best one. We ask that you think about your life in the last four weeks.

\begin{tabular}{ccccccc}
\hline & Very poor & poor & $\begin{array}{c}\text { Neither poor } \\
\text { nor good }\end{array}$ & Good & Very good \\
\hline $1 \quad \begin{array}{c}\text { How would you rate } \\
\text { your quality of life? }\end{array}$ & 1 & 2 & 3 & 4 & 5 \\
\hline \multicolumn{7}{c}{ Very } \\
& dissatisfied & Dissatisfied & $\begin{array}{c}\text { Neither } \\
\text { satisfied nor } \\
\text { dissatisfied }\end{array}$ & Satisfied & $\begin{array}{c}\text { Very } \\
\text { satisfied }\end{array}$ \\
\hline 2 & $\begin{array}{c}\text { How satisfied are you } \\
\text { with your health? }\end{array}$ & 1 & 2 & 3 & 4 & 5 \\
\hline
\end{tabular}

The following question asks about how much you have experienced certain things in the last four weeks.

\begin{tabular}{cccccc}
\hline & Not at all & A little & $\begin{array}{c}\text { A moderate } \\
\text { amount }\end{array}$ & Very much & $\begin{array}{c}\text { An extreme } \\
\text { amount }\end{array}$ \\
\hline $\begin{array}{c}\text { To what extend do you feel } \\
\text { that physical pain/problem } \\
\text { prevents you from doing } \\
\text { what you need to do? }\end{array}$ & 5 & 4 & 3 & 2 & 1 \\
$\quad \begin{array}{l}\text { How much do you need } \\
\text { any medical treatment to } \\
\text { function in your daily life? }\end{array}$ & 5 & 4 & 3 & 2 & 1 \\
$5 \quad$ How much do you enjoy life? & 1 & 2 & 3 & 4 & 5 \\
$6 \quad \begin{array}{c}\text { To what extent do you feel } \\
\text { your life to be meaningful? }\end{array}$ & 1 & 2 & 3 & 4 & 5 \\
\hline
\end{tabular}




\begin{tabular}{cccccc}
\hline & Not at all & A little & $\begin{array}{c}\text { A moderate } \\
\text { amount }\end{array}$ & Very much & Extremely \\
\hline $7 \quad \begin{array}{c}\text { How well are you able } \\
\text { to concentrate? }\end{array}$ & 1 & 2 & 3 & 4 & 5 \\
$8 \quad \begin{array}{c}\text { How safe do you feel in } \\
\text { your daily life? }\end{array}$ & 1 & 2 & 3 & 4 & 5 \\
$9 \quad \begin{array}{c}\text { How healthy is your } \\
\text { physical environment? }\end{array}$ & 1 & 2 & 3 & 4 & 5 \\
\hline
\end{tabular}

The following question asks about how completely you experience or were able to do certain things in the last four weeks.

\begin{tabular}{|c|c|c|c|c|c|c|}
\hline & & Not at all & A little & Moderately & Mostly & Completely \\
\hline 10 & $\begin{array}{l}\text { Do you have enough energy } \\
\text { for everyday life? }\end{array}$ & 1 & 2 & 3 & 4 & 5 \\
\hline 11 & $\begin{array}{c}\text { Are you able to accept your } \\
\text { bodily appearance? }\end{array}$ & 1 & 2 & 3 & 4 & 5 \\
\hline 12 & $\begin{array}{l}\text { Have you enough money to } \\
\text { meet your needs? }\end{array}$ & 1 & 2 & 3 & 4 & 5 \\
\hline 13 & $\begin{array}{l}\text { How available to you is the } \\
\text { information that you need } \\
\text { in our day-to-day life? }\end{array}$ & 1 & 2 & 3 & 4 & 5 \\
\hline \multirow[t]{2}{*}{14} & $\begin{array}{l}\text { To what extent do you have } \\
\text { the opportunity for leisure? }\end{array}$ & 1 & 2 & 3 & 4 & 5 \\
\hline & & Very poor & poor & $\begin{array}{l}\text { Neither poor } \\
\text { nor good }\end{array}$ & Good & Very good \\
\hline \multirow[t]{2}{*}{15} & $\begin{array}{l}\text { How well are you able } \\
\text { to get around? }\end{array}$ & 1 & 2 & 3 & 4 & 5 \\
\hline & & $\begin{array}{c}\text { Very } \\
\text { dissatisfied }\end{array}$ & Dissatisfied & $\begin{array}{l}\text { Neither } \\
\text { satisfied nor } \\
\text { dissatisfied }\end{array}$ & Satisfied & $\begin{array}{c}\text { Very } \\
\text { satisfied }\end{array}$ \\
\hline 16 & $\begin{array}{l}\text { How satisfied are you } \\
\text { with your sleep? }\end{array}$ & 1 & 2 & 3 & 4 & 5 \\
\hline 17 & $\begin{array}{l}\text { How satisfied are you with } \\
\text { your ability to perform your } \\
\text { daily living activities? }\end{array}$ & 1 & 2 & 3 & 4 & 5 \\
\hline 18 & $\begin{array}{l}\text { How satisfied are you with } \\
\text { your capacity for work? }\end{array}$ & 1 & 2 & 3 & 4 & 5 \\
\hline 19 & $\begin{array}{l}\text { How satisfied are you } \\
\text { with yourself? }\end{array}$ & 1 & 2 & 3 & 4 & 5 \\
\hline
\end{tabular}




\begin{tabular}{|c|c|c|c|c|c|c|}
\hline 20 & $\begin{array}{l}\text { How satisfied are you with } \\
\text { your personal relationship? }\end{array}$ & 1 & 2 & 3 & 4 & 5 \\
\hline 21 & $\begin{array}{c}\text { How satisfied are you with } \\
\text { your sex life? }\end{array}$ & 1 & 2 & 3 & 4 & 5 \\
\hline 22 & $\begin{array}{c}\text { How satisfied are you with } \\
\text { the support you get from } \\
\text { your friends? }\end{array}$ & 1 & 2 & 3 & 4 & 5 \\
\hline 23 & $\begin{array}{c}\text { How satisfied are you with } \\
\text { the conditions of your } \\
\text { living place? }\end{array}$ & 1 & 2 & 3 & 4 & 5 \\
\hline 24 & $\begin{array}{l}\text { How satisfied are you with } \\
\text { your access to health services? }\end{array}$ & 1 & 2 & 3 & 4 & 5 \\
\hline 25 & $\begin{array}{l}\text { How satisfied are you } \\
\text { with your transport? }\end{array}$ & 1 & 2 & 3 & 4 & 5 \\
\hline
\end{tabular}

The following question refers to how often you have felt or experienced certain things in the last four weeks.

\begin{tabular}{lccccc}
\hline & Never & Seldom & Quite often & Very often & Always \\
\hline $26 \quad \begin{array}{c}\text { How often do you have } \\
\text { negative feelings such as } \\
\text { blue mood, despair, } \\
\text { anxiety, depression? }\end{array}$ & 5 & 4 & 3 & 2 & 1 \\
\hline
\end{tabular}

